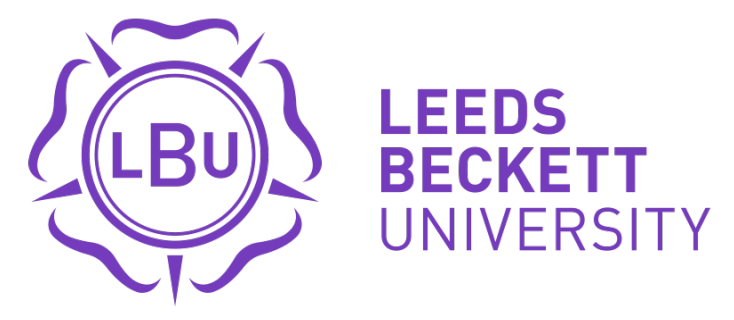

Citation:

Oyedele, LO and Ajayi, SO and Kadiri, KO (2014) Use of recycled products in UK construction industry: An empirical investigation into critical impediments and strategies for improvement. Resources, Conservation and Recycling, 93. pp. 23-31. ISSN 0921-3449 DOI: https://doi.org/10.1016/j.resconrec.2014.09.011

Link to Leeds Beckett Repository record:

https://eprints.leedsbeckett.ac.uk/id/eprint/3224/

Document Version:

Article (Accepted Version)

The aim of the Leeds Beckett Repository is to provide open access to our research, as required by funder policies and permitted by publishers and copyright law.

The Leeds Beckett repository holds a wide range of publications, each of which has been checked for copyright and the relevant embargo period has been applied by the Research Services team.

We operate on a standard take-down policy. If you are the author or publisher of an output and you would like it removed from the repository, please contact us and we will investigate on a case-by-case basis.

Each thesis in the repository has been cleared where necessary by the author for third party copyright. If you would like a thesis to be removed from the repository or believe there is an issue with copyright, please contact us on openaccess@leedsbeckett.ac.uk and we will investigate on a case-by-case basis. 


\title{
Use of Recycled Products in UK Construction Industry: An Empirical Investigation into Critical Impediments and Strategies for Improvement
}

\begin{abstract}
Construction industry consumes about half of all material resources taken from nature, and generates a large portion of waste to landfill. A way of tackling negative environmental impacts impending from continuous material extraction and waste generation is the use of recycled materials for construction projects. However, the use of recycled materials is yet to become a commonplace in construction industry. This study evaluates the factors hampering the use of recycled products in UK construction industry as well as strategies that could be adopted to enhance its use in the industry. In order to identify the impediments and critical strategies, a two-fold methodical approach was used. An unstructured interview preceded a quantitative questionnaire survey which was used to elicit broader industry practitioners' opinion.
\end{abstract}

The study shows that designers rarely specify recycled products. This is due to lack of adequate information about quality and market availability of the products, negative perception from clients, and unexpectedly high cost of the products, despite its perceived low quality. The study suggests that a number of strategies could be adopted to promote the use of the products. These include allocation of points to the use of recycled products in sustainable design appraisal tools, governments legislative measures, improved collaboration between designers, contractors and materials supplier, contractors involvement at earlier stage of design, improved education of the professionals about the products, and the use of tax break to influence the cost of the products. The findings of this study would therefore help policy makers, manufacturers and construction professionals to identify the factors hampering the use of recycled products for construction projects as well as the strategies that could be adopted in order to create market for the products.

Key Words: Recycled Products; Construction Industry; Impediments and Strategies; Landfill; Specification 


\subsection{Introduction}

All over the world, construction industry consumes up to $50 \%$ of all material resources taken from nature (Anink et al, 1996); and in developed nations, construction industry is the largest consumer of material resources (WRAP, 2009). Continuous extraction of these natural resources among other human's negative environmental activities have far reaching impacts not only on materials depletion (WRAP, 2009), it also affects environmental biodiversity, increases the tendencies of greenhouse effects and $\mathrm{CO}_{2}$ emission among other environmental hazards (Treolar et al, 2003; Shen and Tam, 2002).

Various studies confirmed that excavation, transportation and processing of the natural resources used in producing virgin construction materials and products consume highest portion of energy, next to operational energy, over the entire lifecycle of buildings (Utama et al, 2012; Sartori and Hestnes, 2007; Ramesh et al, 2010; Anink et al, 1996). Similarly, construction industry accounts for the largest portion of global waste and pollution (Faniran and Caban, 1998; Ibrahim et al, 2010), up to 30\% of global waste (Begum et al, 2009). For instance, UK Construction and Demolition Waste (CDEW) amounts to about 110 million tonnes, which is over $60 \%$ of national waste generated (Paine and Dhir, 2010). Construction related waste is up to $40 \%$ in Brazil (Saraiva et al, 2012), 27\% in Canada (Yeheyis et al, 2013), 44\% in Australia (Shen and Tam, 2002), 25\% in Hong Kong (Lu and Tam, 2013), and up to $29 \%$ in the US (Yu et al, 2013). These worrying figures did not only give more justification for EU government's target of 70\% recycling of CDEW and 50\% recycling of household waste in the year 2020 (Department for Environment, 2011; Saez et al., 2012), it also suggest that the need for the construction industry to reduce its consumption of virgin materials and waste to landfill is indispensable to the global sustainable development agenda.

As such, various governments across the world - especially in the developed nations - are continuously setting targets towards reducing the environmental impacts as a result of their construction activities. Among these means of reducing environmental impacts due to construction activities are various government led campaign, legislation and initiatives such as the use of BREEAM and Code for Sustainable Homes (CfSH) for sustainable building appraisal, Site Waste Management Plan (SWMP), Aggregate Levy, and the imposition of landfill tax to discourage waste to landfill, and to promote materials re-use and recycling.

One of the proven means through which waste have been diverted from landfill is through recycling of the waste products (Dunster, 2012). Construction industry does not only have the 
potential of using its own waste for further construction activities, several domestic waste and post-consumer materials have been used in the production of construction materials. Although, it is argued that recycling operations are not without environmental problems due to materials transportation and actual recycling processes (Saraiva et al, 2012), it still remains a preferable option to landfilling (Benjamin, 2010, Chong and Hermreck, 2010).Use of recycled materials helps in reducing the need for materials extraction which would have resulted into material depletion and other environmental problems (WRAP, 2009; Halliday, 2008).

Despite the environmental benefit that accrue to recycling of construction, post-consumer and industrial waste and its ultimate use in construction, studies show that recycled materials have been under-utilised in construction projects while its acceptance is still low within the construction industry (WRAP, 2010; Mansikkasalo, et al 2013). Although there is well established market for recycled concrete as a construction materials (Watts and Partners, 2008), Addis (2006) points out that less progress has been made regarding integration of other recycled products into large projects being undertaken by mainstream contractors, design engineers and architects. Similarly, it is clear that despite the availability of recycled products in construction market, its specification, adoption and market growth is relatively slow (WRAP, 2010; Chick and Micklethwaite, 2003).

Meanwhile, along with studies regarding importance and environmental benefits of waste recycling (Tiemstra, 2002; Chen et al, 2009; EEA, 2012), several studies have been carried out on minimization of waste to landfill (Oyedele et al, 2013; Tam et al, 2007; Corvellec and Hultman, 2012). Recent studies on recycling have also focussed on the use of recycled aggregates in various construction activities (Cavalline and Weggel, 2013; Richardson et al, 2009; Nassar and Soroushian, 2012; Kanellopoulos et al, 2014). Concurrently, several other studies have focused on recycling behaviour among people of varying background (Ramayah and Rahbar, 2013; Bezzina and Dimech, 2011; Pike et al, 2003). Unfortunately, apart from those with limited theoretical knowledge on the subject area (e.g. Treolar et al, 2003; Chick and Micklethwaite, 2003), no research efforts has been made to determine the impediments to the use of recycled materials in construction projects.

Similarly, despite the low adoption of recycling product across construction projects, government have only set target for waste recycling, without any research efforts to evaluate 
the barriers to the use of recycled products as well as strategies for improving its use by construction professionals. This represents a gap in knowledge which this study is set to fill.

As such, this study is aimed at investigating the impediments to the use of recycled materials and products in construction projects, and strategies that could improve its wide adoption in construction industry. Therefore, the objectives of the study are to evaluate the perspectives of construction professionals (designers and contractors) on impediments to wide adoption of recycled materials in the industry, as well as strategies that could be adopted to improve the use of recycled products in construction projects. The study would help policy makers in providing the right platforms to enhance the use of recycled products in construction projects, thereby creating markets for the products, especially as policies continuously enhance waste recycling.

\subsection{Recycled Construction Materials and its market}

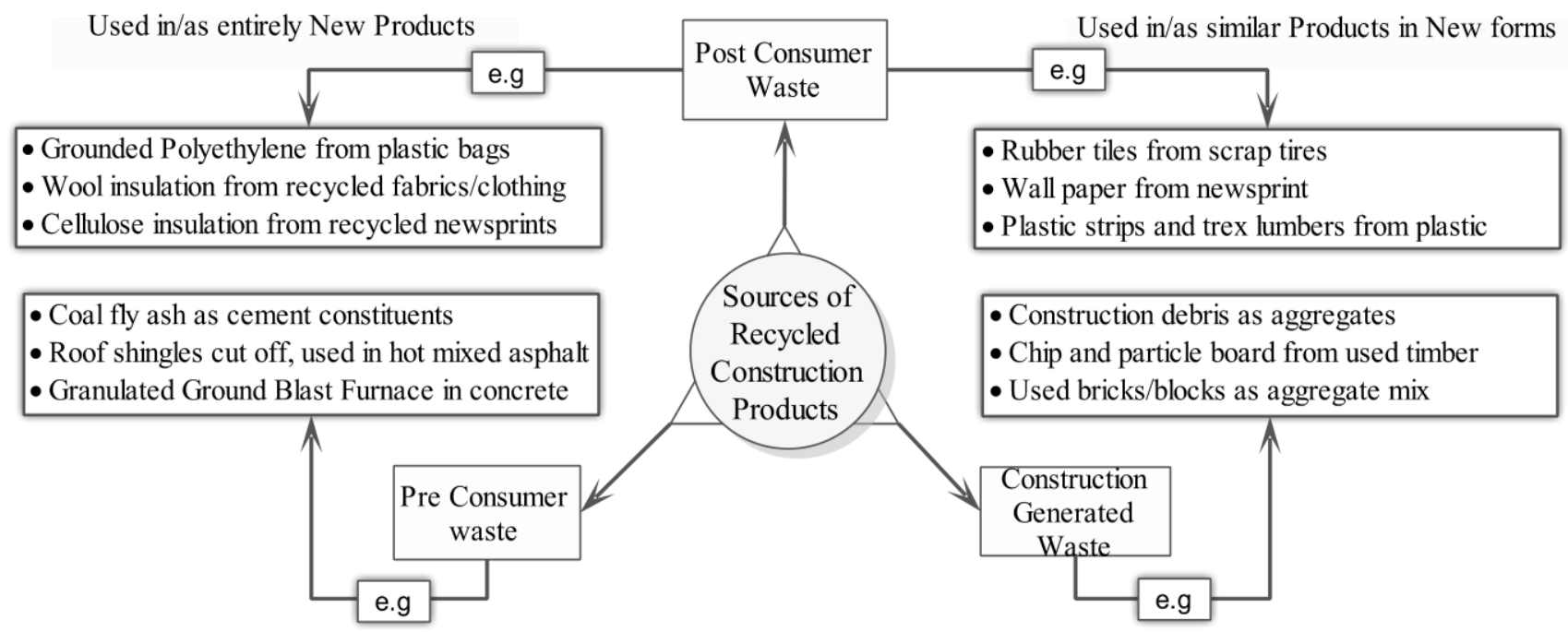

Figure 1: Classification of Recycled Construction Materials

\subsection{Recycled Waste as Construction Materials}

Waste from different origins (see figure 1) have become sources of various construction products. For instance, post-consumer waste generated from commercial, households, institution or industrial uses is recycled for use in construction. Examples of such materials 
include newsprint for cellulose insulation, wall paper, asphalt road surfacing and colour board; plastic bags for plastic strip usually added to soil embankments, grounded polyethylene, and as a constituent of Trex and plastic lumber (Bolden et al, 2013; Woolley et al, 1997; Graettinger, et al, 2005). Other recycled products of post-consumer origin include wool insulation made from recycled fabrics, ceiling boards made from recycled plastics, carpet and carpet pad made from recycled post-consumer fabrics, rubber tiles made from scrap tires, and so on.

Industrial waste, otherwise known as pre-consumer materials refers to those materials that are diverted from waste stream during industrial manufacturing process (WRAP, 2009). More common in construction industry is coal fly ash, which is powdery substance, produced as a result of combustion of coal. Other pre-consumer materials include roof shingles cut-offs used as constituent of Hot Mix Asphalt (HMA), Granulated Ground Blast Furnace Slag (GGBFS) used as constituent of cement mix (El-Assaly and Ellis, 2001; Bolden et al, 2013), etc.

Construction materials waste is also a source of new construction materials or constituents of other products (Saraiva et al, 2012). However, quality of recycled construction products remains a big subject of controversial literatures. According to Medina et al, (2014), while some studies (such as Mefteh et al, 2013; Etxeberria et al, 2007) claim that the quality of concrete reduces with increasing recycled concrete aggregate, others (Yang et al, 2011; Thomas et al. 2013) argue that the quality of concrete remains unaffected as a result of recycled aggregate. Nevertheless, because construction generates a substantial proportions of landfill waste, and it is still expected to continuously increase (Knoeria et al, 2011), recycling and marketability of waste generated from construction activities is without doubt, a holistic approach to reduce the net amount of waste generated from construction activities.

\subsection{Marketability of Recycled Products}

Generally, sustainable construction materials, among which recycled products are included, have been driven by various government policies as a result of global sustainable development agenda (Watts and Partners, 2008). Nevertheless, there has been slow development of recycled materials market (Chick and Micklethwaite, 2003; Mansikkasalo et al. 2013). This is because, apart from the fact that there is no guarantee market and conventional specification for recycled products, architects and other designers feel that it requires additional time to source for the products (WRAP, 2010, CIRIA, 1999; Sassi and Thompson, 
2008), while projects are always within constrained time frame. However, Addis (2006) argues that there is readily available information on recycled product; although, he believes that such information might not totally address the needs of designers.

Similarly, Spoerri et al (2009) affirm that there is little market demand for recycled products, and this has hindered the success of recycling programs. Some of the well debated factors hindering recycled products market are cost and quality of the products (Essoussi and Linton, 2010). While it is widely believed that recycled products are more expensive than virgin product, as a result of series of manual labour involved in its processing (Seydal et al, 2002; Essoussi and Linton, 2010), others believe that recycled products are cheaper than virgin materials (Watson, 2008; Hanyu et al. 2000). Addis (2006) however clarifies that the cost of recycled products is unpredictable with reference to their virgin counterpart; it totally depends on the nature of the materials in question. Nevertheless, studies found out that if they are well sensitised, consumers are more likely to pay a moderate premium for environmental friendly materials (Vlosky et al. 1999; Laroche et al. 2001).

\subsection{Research Methodology}

To fulfil the overall goal of determining impediments to the use of recycled products as well as strategies to improve its specification and use in construction projects, this study employed two-fold methodological approach. It involved a qualitative theoretical research along with unstructured interview which provided information that formed basis for quantitative study.

\subsection{Qualitative Data Collection}

Few existing studies and government publications relevant to the subject area were identified and critically analysed. This was corroborated with an unstructured interview of major stakeholders involved in the specification and use of recycled materials - designers (architects and design engineers) and contractors. The respondents were approached based on the types of firm they work. Overall, a total of 10 construction industry professionals were interviewed, 6 working in design firms, while others are working for construction firms across the UK. The selection of these 10 professionals was based on convenience sampling using the research team's network of contacts within the UK construction industry. Similar studies within construction management field that have used this sampling method include 
Akintoye et al., (1998) and Oyedele (2013). With none of the interview respondents having less than 5 years of experience in the UK construction industry, the informants were asked to describe the factors that are likely to prevent them from specifying and/or use recycled products in construction projects. They were also asked to comment on the level of hindrance caused by these factors as well as what could be put in place to encourage the use of recycled products in their projects. Combining the literature and interview scripts, 19 factors inhibiting the use of recycled materials were identified, while 17 factors that could encourage the specification and use of recycled products were also identified after transcribing the interview. The factors are presented in table 1 and 2 .

\subsection{Quantitative Data Collection}

In order to elicit broader opinion from industry practitioners, the identified factors were incorporated into a questionnaire survey. The questionnaires were pilot tested so as to determine its adequacy to provide answers to the research questions, as well as to ensure that the respondents would adequately understand every requirement of the research instrument. As a result of comments and little ambiguity observed in the questionnaire, necessary modifications were made to the questionnaire consisting of the factors and demographical information about the respondents. The questionnaire was rated on 5-point Likert scale where 1 and 5 represent "strongly disagree" and "strongly agree" respectively.

A total of 200 questionnaires were randomly distributed to designers and contactors across the UK using directories of UK construction professionals. These include Royal Institute of Chartered Surveyors (RICS), Chartered Institute of Building (CIOB), Royal Institute of British Architects (RIBA), Association of Project Mangers (APM), Institution of Civil Engineers (ICE), Institution of Structural Engineers (IStructE), Chartered Institute of Building Service Engineers (CIBSE) and Association of Consulting Engineers (ACE). 182 respondents returned their questionnaire; this represents $91 \%$ response rate. However, out of the 182 questionnaire, only 154 were fully completed and were finally used for further analysis. Out of the 154 participants, 72 were from design firms while 82 were from construction firms; this represents $46.7 \%$ and $53.3 \%$ for designers and contractors respectively. 


\subsection{Data Analysis}

The purpose of questionnaire analysis in this study was to determine top rated factors inhibiting the use of recycled product, as well as the top rated strategies that could be adopted to promote the use of the products in construction projects. Analysis was also carried out to determine whether there are differences in the opinion of specialists in design firms and construction firms regarding the ranking of those factors. As such, the analysis included descriptive statistics (mean testing) and Mann-Whitney U test, using Statistical Package for Social Science (SPSS).

Descriptive mean testing is a measure of central tendency that is employed in statistical analysis to determine the mean of a set of statistical data (Field, 2009). In this study, descriptive mean test was employed to determine the top rated impediments to the use of recycled products in construction projects as well as the ranking of the strategies that could be employed to improve their wide usage. The higher the mean value of each factor, the higher the ranking of the factor by the respondents. This is because, with regards to the Likert-scale used in the study, the more the value tends to 5, it tends to "strongly agree", and the more it tends to 1 , it tends to "strongly disagree".

Mann-Whitney $U$ test on the other hand is a non-parametric test of null hypothesis that is used in statistical analysis to determine whether two populations are the same or differ against a particular hypothesis (Gupta, 1999). This test is suitable in this regards as the populations are in 2 categories, that is, designers and contractors. Otherwise, Kruskal-Wallis test may be employed instead of Mann-Whitney $U$ test, when the sample is more than 2 categories (Field, 2009). A p-value greater than 0.05 means that the difference between the population about the hypothesis is insignificant; however, if the p-value is less than 0.05 , it shows that their difference regarding the hypothesis is significant beyond 5\% level (Kinnear and Gray, 1999). In this regards, Mann-Whitney U test was used to determine statistical difference between how the designers and contractors view the factors identified in this study. 
Table 1: Impediments to the Use of Recycled Construction products

\begin{tabular}{|c|c|c|c|c|c|c|c|c|c|}
\hline \multirow[b]{2}{*}{ Nos. } & \multirow[b]{2}{*}{ Impediments } & \multirow{2}{*}{$\begin{array}{l}\text { Overall } \\
\text { Mean }\end{array}$} & \multirow{2}{*}{$\begin{array}{l}\text { Overall } \\
\text { Raking }\end{array}$} & \multirow{2}{*}{$\begin{array}{l}\text { Designers } \\
\text { Mean }\end{array}$} & \multirow{2}{*}{$\begin{array}{c}\text { Designers } \\
\text { Ranking }\end{array}$} & \multirow{2}{*}{$\begin{array}{l}\text { Contractors } \\
\text { Mean }\end{array}$} & \multirow{2}{*}{$\begin{array}{l}\text { Contractors } \\
\text { Ranking }\end{array}$} & \multicolumn{2}{|c|}{ Mann Whitney U } \\
\hline & & & & & & & & Z Statistic & Sig. ${ }^{b}$ \\
\hline 1 & $\begin{array}{l}\text { Architects and design engineers do not consider recycled materials } \\
\text { and products during project design and specification }\end{array}$ & 3.55 & 1 & 3.39 & 2 & 3.68 & 1 & -1.116 & 0.264 \\
\hline 2 & Lack of positive perception from clients who drive project process & 3.52 & 2 & 3.14 & 5 & 3.59 & 3 & -2.515 & 0.012 \\
\hline 3 & $\begin{array}{l}\text { Uncertainty on whole life durability of recycled materials and } \\
\text { products }\end{array}$ & 3.47 & 3 & 3.11 & 7 & 3.02 & 9 & -0.994 & 0.32 \\
\hline 4 & $\begin{array}{l}\text { Materials selection and specification are influenced by cost rather } \\
\text { than environmental benefits }\end{array}$ & 3.43 & 4 & 2.11 & 19 & 2.46 & 19 & -1.951 & 0.051 \\
\hline 5 & $\begin{array}{l}\text { Recycled Materials and products are more expensive than } \\
\text { expected due to perceived environmental friendliness }\end{array}$ & 3.38 & 5 & 2.92 & 9 & 2.90 & 13 & -1.727 & 0.084 \\
\hline 6 & Building control hindering the use of recycled materials & 3.18 & 6 & 3.06 & 8 & 3.29 & 5 & -0.772 & 0.44 \\
\hline 7 & Suppliers' websites lack substantial product information & 3.08 & 7 & 2.89 & 11 & 3.24 & 7 & -1.184 & 0.236 \\
\hline 8 & Recycled materials product information is difficult to find & 3.07 & 8 & 3.36 & 3 & 3.56 & 4 & -0.138 & 0.89 \\
\hline 9 & Difficult to find suppliers of Recycled materials & 3.04 & 9 & 3.19 & 4 & 2.90 & 13 & -1.375 & 0.169 \\
\hline 10 & $\begin{array}{l}\text { There is inadequate education about recycled materials and } \\
\text { products in schools }\end{array}$ & 2.95 & 10 & 2.81 & 13 & 3.05 & 8 & -0.788 & 0.431 \\
\hline 11 & Samples of Recycled materials are difficult to obtain & 2.93 & 11 & 2.89 & 11 & 2.98 & 11 & -0.241 & 0.81 \\
\hline 12 & $\begin{array}{l}\text { Industry professionals are not versed enough on recycled materials } \\
\text { and products }\end{array}$ & 2.90 & 12 & 3.81 & 1 & 3.27 & 6 & -0.021 & 0.983 \\
\hline 13 & $\begin{array}{l}\text { Recycled materials does not always meet projects needs and } \\
\text { quality requirements }\end{array}$ & 2.89 & 13 & 2.92 & 9 & 2.89 & 15 & -0.205 & 0.837 \\
\hline 14 & Supply of recycled materials is not always of the same quality & 2.88 & 14 & 2.81 & 13 & 2.95 & 12 & -0.599 & 0.549 \\
\hline 15 & Market supply of recycled materials is not always reliable & 2.80 & 15 & 2.75 & 15 & 2.83 & 16 & -0.419 & 0.675 \\
\hline 16 & $\begin{array}{l}\text { There is a perceived culture among construction professionals that } \\
\text { Recycled materials and products are inferior }\end{array}$ & 2.69 & 16 & 2.67 & 17 & 2.71 & 17 & -0.218 & 0.827 \\
\hline 17 & $\begin{array}{l}\text { Level of recycled contents in products is not always clear and easy } \\
\text { to find }\end{array}$ & 2.68 & 17 & 2.69 & 16 & 2.68 & 18 & -0.043 & 0.966 \\
\hline 18 & Legislation prevents the use of Recycled Products and Materials & 2.66 & 18 & 2.25 & 18 & 3.02 & 9 & -2.964 & 0.003 \\
\hline 19 & Lack of tax breaks for contractors & 2.30 & 19 & 3.14 & 5 & 3.65 & 2 & -1.307 & 0.191 \\
\hline
\end{tabular}

Note: ${ }^{b}$ Significant at $95 \%$ Confidence Interval $=0.05$ 


\begin{tabular}{|c|c|c|c|c|c|c|c|c|c|}
\hline \multirow[b]{2}{*}{ Nos. } & \multirow[b]{2}{*}{ Strategies } & \multirow{2}{*}{$\begin{array}{l}\text { Overall } \\
\text { Mean }\end{array}$} & \multirow{2}{*}{$\begin{array}{l}\text { Overall } \\
\text { Raking }\end{array}$} & \multirow{2}{*}{$\begin{array}{c}\text { Designers } \\
\text { Mean }\end{array}$} & \multirow{2}{*}{$\begin{array}{c}\text { Designers } \\
\text { Ranking }\end{array}$} & \multirow{2}{*}{$\begin{array}{c}\text { Contractors } \\
\text { Mean }\end{array}$} & \multirow{2}{*}{$\begin{array}{c}\text { Contractors } \\
\text { Ranking }\end{array}$} & \multicolumn{2}{|c|}{ Mann-Whitney U } \\
\hline & & & & & & & & Z Statistic & Sig. ${ }^{b}$ \\
\hline 1 & $\begin{array}{l}\text { Allocation of more points to the use of recycled materials in sustainable } \\
\text { design appraisal tools }\end{array}$ & 4.20 & 1 & 4.36 & 2 & 4.06 & 2 & -1.234 & 0.217 \\
\hline 2 & $\begin{array}{l}\text { Government legislation that would set target for the usage of recycled } \\
\text { materials and products }\end{array}$ & 4.20 & 1 & 4.41 & 1 & 4.00 & 3 & -1.952 & 0.051 \\
\hline 3 & $\begin{array}{l}\text { Improved architects and Contractors supply chain alliances with } \\
\text { suppliers/recycling companies }\end{array}$ & 4.13 & 2 & 4.08 & 5 & 4.17 & 1 & -0.161 & 0.876 \\
\hline 4 & Early contractors involvement during materials specification & 4.09 & 4 & 4.24 & 3 & 3.97 & 4 & -0.875 & 0.381 \\
\hline 5 & Improved education of construction professionals & 4.02 & 5 & 4.20 & 4 & 3.86 & 6 & -1.925 & 0.054 \\
\hline 6 & Tax break for companies producing recycled materials and products & 3.85 & 6 & 3.88 & 6 & 3.83 & 7 & 0.000 & 1.000 \\
\hline 7 & $\begin{array}{l}\text { Early supply chain/recycling companies involvement in design and } \\
\text { materials specifications }\end{array}$ & 3.83 & 7 & 3.76 & 7 & 3.87 & 5 & -0.731 & 0.464 \\
\hline 8 & $\begin{array}{l}\text { Professional bodies to improve awareness and benefits of recyclable } \\
\text { materials and products among their members }\end{array}$ & 3.67 & 8 & 3.60 & 11 & 3.72 & 9 & -0.512 & 0.609 \\
\hline 9 & Dedicated specialists for material specification during design stage & 3.65 & 9 & 3.68 & 10 & 3.62 & 10 & -0.333 & 0.739 \\
\hline 11 & $\begin{array}{l}\text { Projects contractual clauses that would make compulsion, the usage of } \\
\text { recycled products and materials }\end{array}$ & 3.61 & 11 & 3.76 & 7 & 3.48 & 12 & -0.662 & 0.508 \\
\hline 12 & $\begin{array}{l}\text { Research and development to improve and produce varieties of recycled } \\
\text { materials and products }\end{array}$ & 3.56 & 12 & 3.60 & 11 & 3.51 & 11 & -0.344 & 0.731 \\
\hline 13 & $\begin{array}{l}\text { Development of an online database of recycled materials and associated } \\
\text { suppliers }\end{array}$ & 3.52 & 13 & 3.72 & 9 & 3.34 & 14 & -1.973 & 0.048 \\
\hline 14 & Evaluation of recycling opportunities inherent in materials at design stage & 3.39 & 14 & 3.37 & 14 & 3.37 & 13 & -0.318 & 0.750 \\
\hline 15 & $\begin{array}{l}\text { Government to provide financial incentives for the usage of recycled } \\
\text { materials in projects }\end{array}$ & 3.31 & 15 & 3.32 & 15 & 3.31 & 15 & -0.527 & 0.598 \\
\hline 16 & $\begin{array}{l}\text { Use of computer modelling tools to visualise environmental benefits of } \\
\text { recycled materials and products }\end{array}$ & 3.06 & 16 & 3.04 & 16 & 3.07 & 17 & -0.337 & 0.736 \\
\hline 17 & $\begin{array}{l}\text { Provision of legislation that would require product manufacturers to } \\
\text { specify level of recycled content in their products }\end{array}$ & 2.96 & 17 & 2.80 & 17 & 3.10 & 16 & -1.569 & 0.117 \\
\hline
\end{tabular}

Note: ${ }^{b}$ Significant at $95 \%$ Confidence Interval $=0.05$ 


\subsection{Result and Discussion}

Table 1 and 2 present findings from the statistical analysis. From the tables, it could be seen that the impediments to the use of recycled products in construction are viewed in different but similar perspectives by designers and contractors. The impediments and strategies are also rated higher than one another by the respondents. Statistical difference between the designers and contractors as well as the top rated impediments and strategies are further evaluated and discussed in this section.

\subsection{Statistical Difference between Designers' and Contractors' Ranking of the Impediments}

Mann-Whitney U test (see Table 1) shows a significant difference between the way designers and contractors view two of the factors impeding the use of recycled products in construction; these factors are "lack of positive perception from clients who drive the project" and "legislation prevents the use of recycled products". Although, "lack of positive perception from client" is highly rated by both teams, a mean rank of 3.59 against 3.14 by the designers shows that the factor was strongly upheld by the contractors. This could be explained by the fact that although designers could specify the products, lack of technical understanding of specification might make it difficult for the clients to reject the use of recycled products until the start of actual construction phase. At this stage, the client would show their negative perception about the materials; this possibly explains the higher mean value given to the factor by the contractors.

Similarly, another significant statistically different factor is that "legislation prevents the use of recycled product" which is strongly upheld by the contractor. This may sound rather vague, especially as government is the main promoter of green businesses. However, the reason for this confusing factor could be further explained by the contractors' ranking of "lack of tax break for contractors using recycled products" and "building control hindering the use of recycled products" as $2^{\text {nd }}$ and $5^{\text {th }}$ critical factors. This shows that while designers' inability to use recycled product is basically caused by unavailability of information regarding recycled products (ranked as $1^{\text {st }}$ and $5^{\text {th }}$ by the designers), contractors' inability to use recycled product is majorly due to the lack of compensation from government, who advocates its use. 
Summarily, apart from unanimously ranked factors impeding the use of recycled products, two other factors identified based on separate job position-influenced perception of designers and contractors are inadequate information about market availability of recycled products and lack of compensation for extra efforts required in procuring and subsequent use of recycled products.

\subsection{Statistical Difference between Designers' and Contractors' Ranking of the Strategies}

There is a little difference in the way the designers and contractors rank the strategies for improving the use of recycled products in construction projects. Mann-Whitney U test confirms that there is less significant difference. With the exception of one factor, this shows that adopting the same strategy would improve the specification of recycled materials by the designers as well as its subsequent use by the contractors. The only factor that was perceived statistically different at $95 \%$ confidence interval by both designers and contractors is "Development of an online database of recycled materials and associated suppliers". While designers believe that availability of such materials would enhance the use of the products, the contractors do not strongly share similar view. It was ranked low by both groups of respondents, $9^{\text {th }}$ of 17 by the designers and $14^{\text {th }}$ of 17 by the contractors.

This could be further explained using the impediments to the use of the materials in the projects. It is clear that the main factor impeding the use of the products is the fact that designers rarely specify them during their design as a result of inadequate information about the products. This could be the reason why the designers believe that availability of such database would improve their knowledge of the materials. Additionally, there is little difference in ordering of the strategy factors. The contractors' first seven strategies surprisingly fall within the designers' first seven strategies. This further proves that if the top rated strategies are adopted by the policy makers, academic institutions and the construction professionals (designers and contractors), the use of recycled products would become a common phenomenon within the construction industry. 


\subsection{Impediments to the Use of Recycled Products}

This section discusses the top rated impediments to the use of recycled products in construction projects:

\subsubsection{Designers not considering recycled materials in their specification}

The findings show that the top rated factor hindering the use of recycled products in construction projects is designers' lack of preference for recycled products in their specifications. This finding is not surprising, as it is clear that designers play major role in determining the materials that would be subsequently used in the project. This is due to the fact that designers' specification would definitely influence purchasing decision. It would therefore be worth of investigation to determine the reasons why designers do not specify recycled materials in their projects.

WRAP (2009) admits that although there are green guide ratings which allow designers to know materials that are environmentally friendly, but such documents lack information about the recycled content with which such materials can be substituted. Similarly, when investigating the reasons why UK architects do not specify recycled products, Chick and Micklethwaite (2004) suggest that lack of required information and unfamiliarity with the products are the major obstacles preventing the specialists from specifying the products. This means that apart from placing stringent rules on the use of recycled materials, or encouraging its use, market calls for documents that would give detail information about recycled products that are available for use in construction projects.

\subsubsection{Lack of positive perception from Clients}

Usually, recycled products are perceived as second class materials of low standard and short lifecycle period. This study suggests that apart from the design teams who are responsible for material specification, clients play a major role in determining the nature of materials that would be used in their projects. Gravina da Rocha and Sattler (2009) point out that client always believe that since reused or recycled products have earlier being used, there is general perception that they may not serve their required purpose. This means that without a real change in societal attitude towards the use of recycled materials, little achievement could be made regarding marketability of the products. Although the study shows the clients share this biasness towards recycled products, the reverse is the case when it comes to materials manufacturers and contractor. They are always proud of manufacturing or using recycled 
products, especially as it enhances their brand value in the sustainability driven global environment.

\subsubsection{Uncertainty on whole life durability of recycled products}

One of the highly rated barriers to the use of recycled products is uncertainty about its durability. It is of general concern that recovered waste could arguably result in an inferior product, and there are also need to consider other aspects of design, such as aesthetics and build-ability issues (WRAP, 2009) which recycled products may not always offer along with its environmental friendliness. However, this assumption is not always true of recycled products. Studies suggest that recycled products such as aggregate, cellulose insulation made of recycled newsprints and so on perform either equal or better than virgin products (Halliday, 2008; Thomas et al. 2013). Practical testing and proper stakeholders' education about durability of recycled products could be a better way of enhancing its use, especially as the clients remain the major drivers of every project.

\subsubsection{Materials selection is more influenced by cost than environmental benefits.}

Findings show that selection of materials is not basically influenced by the amount of recycled content or environmental friendliness of such material, it is rather influenced by the cost of the materials and its suitability based on the project cost. It is certain that although renewable and low energy technologies such as the use of PV panel, energy efficient bulbs, wind energy are more costly than their less energy efficient types, their pay-back period always encourage developers, public and private clients to patronise them (Knapp and Jester, 2001).

Similarly, Guagnano (2001) and Laroche et al. (2001) found that a higher percentage of respondents would pay a premium for products labelled as "green". This could be described as a form of environmental behaviour with regards to certain products. This consumers' willingness to pay such premium could also be as a result of shorter payback periods of such products. However, this study suggests that willingness to pay for green product is second to cost when it comes to construction projects and particularly, the use of recycled products. It suggests that, clients and consultants give second attention to environmental friendliness of materials; they rather concentrate on how to work within the project cost before considering environmental benefits. 


\subsubsection{Recycled products are more expensive}

Although recycled construction products go well when environmental issue is addressed, studies however claim that despite recycled products being secondary products, they are more expensive than virgin products (Seydal et al, 2002). Although several studies (mainly governments' publications) claim that recycled products are always cheaper, this could be true in case of such products as toilet tissue and few other products (Hanyu et al, 2000). In case of construction products, it is not always true (Essoussi and Linton, 2010). As such, this has been a major factor hindering its wider acceptability with the construction industry. It means that although governments across developed world have been advocating for increase waste recycling, for its market to be well developed, there would be need for the products to be less costly.

\subsection{Strategies for Enhancing the Use of Recycled Products in Construction.}

In fulfilling the aim and objectives of this study, it is important to discuss the top rated strategies that could be adopted in order to improve the use of recycled materials in construction projects, after evaluating various factors that are impeding the use of the products. They are discussed as follow:

\subsubsection{Allocation of more points to the use of recycled materials in sustainable design} appraisal tools/Government legislation that would set target for the usage of recycled materials and products.

Two highest rated strategies that could improve the use of recycled materials in construction projects are "allocation of more points to the use of recycled materials in sustainable design appraisal tools" and "government legislation that would set target for the usage of recycled materials and products". Sustainable design appraisal tools refer to the government approved tools being used in rating buildings and other construction facilities for the extent of sustainability it has incorporated. They have been developed to evaluate the extent to which the projects have been successful regarding energy use, ecology, water and waste management, and other environmental indicators. These include BREEAM and Code for Sustainable Homes (CfSH) in the UK, LEED in the US, CASBEE in Japan, BEPAC in Canada, Eco-Quantum in Netherland, and so on (Ding, 2008; Lee and Burnett, 2008). 
The stringency of these tools in ensuring environmental and sustainability behaviour among construction industry's specialists have been a proven way of ensuring compliance with national and global governments' sustainability agenda. This study therefore suggests that, in order to ensure a wide acceptability of recycled products as construction material, there would be need to incorporate its use into the sustainable design appraisal tools. It therefore means that, if the use of recycled materials is incorporated into such tools as BREEAM and $\mathrm{CfSH}$ in a similar way that water, energy, waste, etc. are incorporated, its use would contribute to building ratings. This is without doubt, the major strategy that could be adopted to ensure a wide acceptability of recycled materials in construction projects.

In order to ensure its use, government and recycled products manufacturers alike have a major role to play. To create market for the products and subsequently improve its use in construction projects, there would be need for adequate information about available recycled products usable in construction project, rather than just setting target for percentage recycling. This would be imperative, especially as lack of information is seen as a major factor preventing the designers from specifying recycled products.

\subsubsection{Improved architects and Contractors supply chain alliances with suppliers/recycling companies.}

For the use of recycled materials to become a common place in construction industry, this study suggests that there would be need for improved collaboration between the construction specialists and manufacturers of the products. Supply chain collaboration refers to a cooperative strategy whereby businesses work together towards creating mutual benefits (Spekman et al, 1998). Usually, collaboration between members entails easy information management and adequate communication, and it involves a cooperative system (Chandra and Kumar, 2001). Improved collaboration and alliance between designers, suppliers and recycled products manufacturers would therefore break the barriers to information about recycled products. This would without doubt enhance the use of recycled products as widely believed by construction professionals.

Collaboration in this regards would mean that the designers and contractors should work along with products manufacturers from inception to completion of the project. This would allow the consultants to know what is available in terms of recycled materials. Similarly, it is a cooperative system that would request materials manufacturers and suppliers to work along 
with the construction professionals in such a way that they would be carried along at least while testing the materials. This would furnish the professional with the functional capacity of the materials they are specifying as well as the right way of specifying the products. Specification and subsequent use of the materials would therefore be enhanced by adequately furnishing the users with required information about the products.

\subsubsection{Early contractors' involvement during materials specification}

One of the top rated strategies that could improve the use of recycled products in construction projects is involvement of contractors during materials specification. In this case, early contractors' involvement refers to situation whereby contractors are allowed to contribute their expertise knowledge during design stage, so as to deliver the best value for the project (Song et al., 2006). The benefits of such arrangement are immense. Song et al (2009) argues that since they usually have higher level of construction knowledge, contractors are better equipped with knowledge of available materials, local practices and construction methods.

Similarly, Gould (2003) claims that the era of designers and contractors working independently to achieve unimaginable outcome is far gone. Although the industry's culture remains the major barrier to improved collaboration, understanding the benefits of collaboration, such as knowledge sharing, cost saving, time saving, improved performance, etc. would definitely call for the need for cultural change (Song et al, 2009). As such, it is certain that combination of expertise knowledge by the designers and contractors is a good measure not only towards enjoying the aforementioned benefits, but also towards improving their knowledge of recycled materials and their subsequent use in construction projects.

\subsubsection{Improved education of construction professionals.}

The benefits of using recycled materials are well explored across wide ranges of literature (WRAP, 2010; Dunster, 2012; Bolden et al, 2013; Tiemstra, 2002; WRAP, 2009; USEPA, 2011; Treolar et al, 2003). Similarly, there are several publications providing database for construction products (Anink et al, 1996; Halliday, 2008) and their environmental rating (Anderson et al, 2002). However, little have been done to provide database of recycled products and/or recycled contents of various construction materials. This justifies the reason for little knowledge about recycled product as found out in a survey of UK's architects (Chick and Micklethwaite, 2003). 
This study suggests that, in order to improve the use of recycled products in construction projects, there would be need for more research efforts, training and publication about available recycled products. Manufacturers as well as government bodies would need to increase their sensitization of designers as well as contractors about available construction products. Similarly, direct relationship between construction-related education and knowledge capacity of young practitioners is well understood. The design and the entire philosophy of the whole training have to be in line with market expectation of the profession (Salama, 1995). As a result of this, in order to improve the wide acceptability of recycled construction products, this study suggests that academic institution could be the right link. They could lend a helping hand in equipping future designers and contractors with adequate knowledge of recycled construction materials.

\subsubsection{Tax break for companies producing recycled materials and products.}

In a proposition to reduce the cost and subsequent patronage of recycled construction products, respondents believe that a means of improving the use of recycled products is through government's tax break for manufacturers of the products. This is because of the fact that green products usually cost more than their conventional counterparts (Vladas et al, 2010), even despite the perceived substandard quality of recycled products. Government have implemented carbon emission tax, with the aim of encouraging manufacturing companies to reduce their $\mathrm{CO}_{2}$ emission rate (Hoel, 1996; Bo"Hringer and Rutherford, 1996), implementation of tax break policies is another means through which recycled products' manufacturers could be encouraged. This also have a high tendency of reducing the cost of recycled materials, which is one of the major factors impeding its use.

\subsection{Conclusion}

Construction industry consumes a large proportion of material resources taken from nature, and accounts for a very large portion of global waste to landfill compared to other sectors of global economy. One of the holistic ways to prevent the adverse effects of materials consumption and waste generation is to promote the use of recycled materials. This study shows that designers rarely specify recycled materials for construction projects. The reasons for this is not far-fetched; it is associated with inadequate information about recycled products, negative perception about the products, as well as its unexpectedly high cost 
compared to virgin materials. Apart from the cost issues, all the identified impediments to the use of the products are due to insufficient information about availability, durability, qualities and effectiveness of the products for construction projects.

As sustainable design appraisal tools such as BREEAM and the US LEED increases environmental conformity of buildings, allocating points to the use of recycled materials and setting target for percentage of recycled products that must be used in projects are seen as means of enhancing the use of the products in construction projects. By doing this, it is certain that designers would specify and subsequently use the products in their projects in order to secure necessary credits for government's approval. More significant among other strategies worthy of consideration is improved collaboration and alliance between designers, contractors and suppliers/manufacturers of recycled products. This would break the barrier to adequate information and ensure knowledge sharing among the stakeholders. Without doubt, it would lead to positive perception of the products, and the societal attitude towards recycled products would change based on knowledge availability.

Unexpectedly high cost of recycled products, despite its perceived low quality, is a major barrier to its patronage in construction industry. This study suggests a tax break for manufacturers of recycled products in such a way as to reduce their cost of sourcing, manufacturing and distributing the products, with the aim of reducing final market cost of the products. Although it is clear that consumers tend to pay a reasonable premium on environmental friendly products, a fairer price of recycled products along with easy information flow and procurement process would go a long way towards encouraging the use of recycled products in construction projects.

\subsection{References}

Addis, B., (2006). Building with Reclaimed Components and Materials: A Design Handbook for Reuse and Recycling. London: Earthscan.

Akintoye, A., Taylor C. and Fitzgerald, E. (1998). Risk analysis and management of private finance initiative projects. Engineering, Construction and Architectural Management, $5(1), 9-21$ 
Anderson, J., Shiers, D., and Sinclair, M., (2002). The Green Guide to Specification, $3^{\text {rd }}$ edition. Oxford: Blackwell publishing.

Anink, D., Mak, J., and Boonstra, C., (1996). Handbook of Sustainable Building: An Environmental Preference Method for Selection of Materials for Use in Construction and Refurbishment. London: James and James.

Begum, R.A., Siwar, C., Pereira, J.J., and Jaafar, A.H., (2009). Attitude and behavioural factors in waste management in the construction industry of Malaysia. Resources, Conservation, and Recycling, 53(6), pp. 321-328.

Benjamin, D.K., (2010). "Recycling Myths Revisited”. PERC Policy series 47, Montana: Property and Environmental Research Centre (PERC).

Bezzina, F.H., and Dimech, S., (2011). Investigating the determinants of recycling behaviour in Malta. Management of Environmental Quality: An International Journal, 22(4), pp. $463-485$.

Bo“Hringer, C., and Rutherford, T.F., (1997). Carbon Taxes with Exemptions in an Open Economy: A General Equilibrium Analysis of the German Tax Initiative. Journal of Environmental Economics and Management, 32(2), pp. 189 - 203.

Bolden, J., Abu-Lebdeh, T., and Fini, E., (2013). Utilization of Recycled and Waste Materials in Various Construction Applications. American Journal of Environmental Science, $9(1)$, pp. $14-24$.

Cavalline, T.L., and Weggel, D.C., (2013). Recycled brick masonry aggregate concrete:Use of brick masonry from construction and demolition waste as recycled aggregate in concrete. Structural Survey, 31(3), pp. $160-180$.

Chandra, C., and Kumar, S., (2001). Enterprise architectural framework for supply-chain Integration. Industrial Management and Data Systems 101(6), pp. 290 - 303.

Chen, Y.J., Wu, T., and Chen, Y., (2003). The recycling business for sustainability in Taiwan. European Business Review, 21(5), pp. 403 - 417. 
Chick, A., and Micklethwaite, P., (2004). Specifying Recycled: Understanding UK architects and Designers practices and Experience. Design studies, 25(3), pp. 251 - 273.

Chong, W.K., and Hermreck, C., (2011). Modeling the use of transportation energy for recycling construction steel. Clean Technology and Environmental Policy, 13(2), pp. $317-330$.

CIRIA - Construction Industry Research and Information Association, (1999). Waste Minimisation and Recycling in Construction: Boardroom Handbook. London: CIRIA.

Corvellec, H., and Hultman, J., (2012). From "less landfilling" to "wasting less" Societal narratives, socio-materiality, and organizations. Journal of Organizational Change Management, 25(2), pp. 297 - 314.

Coventry, S., Hillier, S., and Woolveridge, C., (1999). The reclaimed and recycled materials handbook. London: CIRIA.

Davis, G., O'Callaghan, F., and Knox, K., (2009). Sustainable attitudes and behaviours amongst a sample of non-academic staff: A case study from an Information Services Department, Griffith University, Brisbane. International Journal of Sustainability in Higher Education, 10(2), pp. 136 - 151.

Department for Environment, (2011). "Government Review of Waste Policy in England 2011". London: Department for Environment, Food and Rural Affairs.

Ding, G.K.C., (2008). Sustainable construction - The role of environmental assessment tools. Journal of Environmental Management, 86(3), pp. 451 - 464.

Dunster, A., (2012). The use of recycled and secondary materials in residential construction. Milton Keynes: NHBC Foundation.

EEA - European Environment Agency, (2012). "Waste opportunities: past and future climate benefits from better municipal waste management in Europe. Management of Environmental Quality: An International Journal, 23(2), pp. 1 - 14. 
El-Assaly, A., and Ellis, R., (2001). Evaluation of recycling waste materials and by-products in highway construction. International Journal of Sustainable Development and World Ecology, 8(4), pp. $299-308$.

Esin, T., and Cosgun, N., (2007). A study conducted to reduce construction waste generation in Turkey. Building and Environment, 42(4), 1667-1674.

Essoussi, L.H., and Linton, J.D., (2010). New or recycled products: how much are consumers willing to pay? Journal of Consumer Marketing, 27(5), pp. 458-468.

Etxeberria, M., Mari, A.R., and Vazquez, E., (2007). Recycled aggregate concrete as structural material. Material and Structure, 40(2007), pp. 529 - 541.

Faniran O.O, and Caban G., (1998). Minimizing waste on construction project sites. Enginnering, Construction and Architectural Management, 5(2), pp. 182-188.

Field, A., (2009); Discovering statistics using SPSS. London: Sage publications.

Gould, F. (2003). Managing the construction process, $3^{\text {rd }}$ edition. Upper Saddle River, New Jersey: Pearson Education, Inc.

Graettinger, A.J., Johnson, P.W., Sunkari, P., Duke, M.C., and Effinger, J., (2005). Recycling of plastic bottles for use as a lightweight geotechnical material. Management of Environmental Quality: An International Journal, 16(6), pp. 658 - 669.

Gravina da Rocha, C., and Sattler, M.A., (2009). A discussion on the reuse of building components in Brazil: An analysis of major social, economical and legal factors. Resources, Conservation and Recycling, 54(2), pp. $104-112$.

Guagnano, G.A., (2001). Altruism and market-like behavior: an analysis of willingness to pay for recycled paper products. Population and Environment, 22(4), pp. 425 - 438.

Gupta, V., (1999). SPSS for beginners. USA: VJ Books Inc. 
Halliday, S., (2008). Sustainable Construction. Oxford: Butterworth-Heinemann.

Hanyu, K., Kishino, H., Yamashita, H., and Hayashi, C., (2000). Linkage between recycling and consumption: a case of toilet paper in Japan. Resources, Conservation and Recycling 30(3), pp. 177-199.

Hoel, M., (1996). Should a carbon tax be differentiated across sectors? Journal of Public Economics, 59, pp. 17-32.

Ibrahim, A.Z., Roy, M.H., Ahmed, Z.U., and Imtiaz, G., (2010). Analysing the dynamics of the global construction industry: past, present and future. Benchmarking: An International Journal, 17(2), pp. $232-252$.

Kanellopoulos, A., Nicolaides, D., and Petrou, M.F., (2014). Mechanical and durability properties of concretes containing recycled lime powder and recycled aggregates. Construction and Building Materials, 53(2014), pp. 253 - 259.

Kinnear, P.R., and Gray, C.D., (1999). SPSS for Windows Made simple, $3^{\text {rd }}$ edition. East Sussex: Psychology Press.

Knapp, K., and Jester, T., (2001). Empirical investigation of the energy payback time for photovoltaic modules. Solar Energy, 71(3), pp. 165-172

Knoeria, C., Binderb, C.R., and Althausa, H., (2011). Decisions on recycling: Construction stakeholders' decisions regarding recycled mineral construction materials. Resources, Conservation and Recycling, 55 (2011), pp. 1039 - 1050.

Laroche, M., Bergeron, J., and Barbaro-Forleo, G., (2001). Targeting consumers who are willing to pay more for environmentally friendly products. Journal of Consumer Marketing, 18(6), pp. $503-520$.

Lee, W.L., and Burnett, J., (2008). Benchmarking energy use assessment of HK-BEAM, BREEAM and LEED. Building and Environment, 43(11), pp. 1882 - 1891. 
Lu, W., and Tam, V.W.Y., (2013). Construction waste management policies and their effectiveness in Hong Kong: A longitudinal review. Renewable and Sustainable Energy Reviews, 23(2013), pp. $214-223$.

Mansikkasalo, A., Lundmark, R., and Patrik Söderholm, P., (2014). Market behavior and policy in the recycled paper industry: A critical survey of price elasticity research. Forest Policy and Economics, 38(2014), pp. 17-29.

Medina, C., Zhu, W., Howind, T., Sánchez de Rojas, M.I., and Frías, M., (2014). Influence of mixed recycled aggregate on the physical - mechanical properties of recycled concrete. Journal of Cleaner Production, (2014), pp. 1 - 10.

Mefteh, H., Kebaïli, O., Oucief, H., Berredjem, L., and Arabi, N., (2013). Influence of moisture conditioning of recycled aggregates on the properties of fresh and hardened concrete. Journal of Cleaner Production, 54(2013), pp. 282-288.

Nassar, R., and Soroushian, P., (2012). Strength and durability of recycled aggregate concrete containing milled glass as partial replacement for cement. Construction and Building Materials, 29 (2012), pp. 368 - 377.

Oyedele, L.O., Regan, M., Meding, J.V., Ahmed, A., Ebohon, O.J., and Elnokaly, A., (2013). Reducing waste to landfill in the UK: identifying impediments and critical solutions. World Journal of Science, Technology and Sustainable Development, 10(2), pp. 131 142.

Paine, K. A., and Dhir, R. K., (2010). Recycled aggregates in concrete: a performance related approach. Magazine of Concrete Research, 62 (7), pp. 519 - 530.

Pike, L., Shannon, T., Lawrimore, K., McGee, A., Taylor, M., and Lamoreaux, G., (2003). Science education and sustainability initiatives: A campus recycling case study shows the importance of opportunity. International Journal of Sustainability in Higher Education, 4(3), pp. $218-229$. 
Ramayah, T., and Rahbar, E., (2013). Greening the environment through recycling: an empirical study. Management of Environmental Quality: An International Journal, 24(6), pp. 782-801.

Ramesh, T., Prakash, R., and Shukla, K. K., (2010). Life cycle energy analysis of buildings: An overview. Energy and Buildings, 42 (2010), pp. $1592-1600$.

Richardson, A.E., Coventry, K. and Graham, S., (2009). Concrete manufacture with ungraded recycled aggregates. Structural Survey, 27(1), pp. $62-70$.

Saez, P., Merino, M., and Porras-Amores, C., (2012). Estimation of construction and demolition waste volume generation in new residential buildings in Spain. Waste Management \& Research, 30(2), pp. 137-146.

Salama, A., (1995). New Trends in Architectural Education: Designing the Design Studio. North Carolina: Tailored Text and Unlimited Potential Publishing.

Saraiva, T.S., Borges, M.M, and Filho, A.C., (2012). "The Importance of Recycling of Construction and Demolition Waste". In Proceeding: 28th Conference, Opportunities, Limits \& Needs Towards an environmentally responsible architecture Lima, Perú 7-9 November, 2012.

Sartori, I., and Hestnes, A. G., (2007). Energy use in the life cycle of conventional and lowenergy buildings: A review article. Energy and Buildings, 39 (3), pp. 249-257.

Sassi, P., and Thompson, M.W., (2008). Summary of a study on the potential of recycling in the building industry and the development of an indexing system to assess the suitability of materials for recycling and the benefits from recycling. London: University of East London.

Seydal, A., Wilson, O.D., and Skitmore, R.M., (2002). Financial Evaluation of Waste Management Methods. Journal of Construction Research, 3(1), pp.161 - 167. 
Shen, L.Y., and. Tam, V.W.Y, (2002). Implementation of environmental management in the Hong Kong construction industry. International Journal of Project Management, 20(7), pp. $535-543$.

Song, L., Mohamed, Y., and AbouRizk, S.M., (2006). Evaluating Contractor's Early Involvement in Design. AACE International Transactions, Morgantown.

Song, L., Mohamed, Y., and AbouRizk, S.M., (2009). Early Contractor Involvement in Design and Its Impacts on Construction Schedule Performance. Performance. Journal of Management in Engineering, 25(1), pp. $12-20$.

Spekman, R.E., Kamauff, J.W., and Myhr, N., (1998). An empirical investigation into supply chain management: A perspective on partnership. Supply Chain Management: An International Journal, 3(2), pp. $53-67$.

Spoerri, A., Lang, D.J., Binder, R.C., and Scholz, W.R., (2009). Expert-based scenarios for strategic waste and resource management planning - C\&D waste recycling in the Canton of Zurich, Switzerland. Resources, Conservation and Recycling, 53(10), pp. $592-600$.

Tam, V.W.Y., Shen, L.Y., Fung, I.W.H., and Wang, J.Y., (2007). Controlling construction waste by implementing governmental ordinances in Hong Kong. Construction Innovation: Information, Process, Management, 7(2), pp. 149 - 166.

Thomas, C., Cimentada, A., Polanco, J.A., Setién, J., Méndez, D., and Rico, J., (2013). Influence of recycled aggregates containing sulphur on properties of recycled aggregate mortar and concrete. Composite Part B: Engineering, 45(1), 474-485.

Tiemstra, J.P., (2002). Wasting time and wasting the earth. International Journal of Social Economics, 29(4), pp. $260-270$.

Treolar, G.J., Gupta, H., Love, P.E.D., and Nguyen, B., (2003). An analysis of factors influencing waste minimisation and use of recycled materials for the construction of residential buildings. Management of Environmental Quality: An International Journal, 14 (1), pp. 134-145. 
USEPA, (2011). Reducing Greenhouse Gas Emission through Recycling and Composting. Seattle, WA: United States Environmental Protection Agency (USEPA).

Utama, N.A., McLellan, B., Gheewala, S.H., and Ishihara, K.N., (2012). Embodied impacts of traditional clay versus modern concrete houses in a tropical regime. Building and Environment, 57, (2012), pp. $362-369$.

Vladas, G., Joshua, T.M., and Bram, V., (2010). Going green to be seen: Status, reputation, and conspicuous conservation. Journal of Personality and Social Psychology, 98(3), pp., $392-404$.

Vlosky, R.P., Ozanne, L.K. and Fontenot, R. (1999). A conceptual model of US consumer willingness-to-pay for environmentally certified wood products. The Journal of Consumer Marketing, 16(2), pp. 116-136.

Watson, M., (2008). A Review of literature and research on public attitudes, perceptions and behaviour relating to remanufactured, repaired and reused products. Report for the Centre for Remanufacturing and Reuse, University of Sheffield.

Watts and Partners, (2008). Watts Pocket Handbook. London: Royal Institute of Chartered Surveyors (RICS).

Woolley, T., Kimmins, S., Harrison, P., and Harrison, R., (1997). Green Building Handbook; A guide to building products and their impact on the environment, Volume 1. London: Spon press.

WRAP - Waste and Resource Action Plan, (2009). "Delivering higher recycled content in construction projects" (online). Available at: http://www.wrapni.org.uk/sites/files/wrap/Delivering\%20higher\%20recycled\%20conte nt\%20in\%20construction\%20projects.pdf. [Accessed: $5^{\text {th }}$ January, 2014].

WRAP, (2010). Environmental Benefits of recycling (online). Available at: http://www.wrap.org.uk/sites/files/wrap/Environmental_benefits_of_recycling_2010_u pdate.3b174d59.8816.pdf. [Accessed: $10^{\text {th }}$ January, 2014]. 
Yang, J., Du, Q., and Bao, Y., (2011). Concrete with recycled concrete aggregate and crushed clay bricks. Construction and Building Materials. 25(4), pp. 1935 - 1945.

Yeheyis, M., Hewage, K., Alam, M.S., Eskicioglu, C., and Sadiq, R., (2013). An overview of construction and demolition waste management in Canada: a lifecycle analysis approach to sustainability. Clean Technologies and Environmental Policy, 15(1), pp. 81 $-91$.

Yu, A.T.W., Poon, C.S., Wong, A., Yip, R., and Jallion, L., (2013). Impact of Construction Waste Disposal Charging Scheme on work practices at construction sites in Hong ong. Waste Management, 33(1), pp. 138 - 146 